\title{
Reversible Energy Storage in Layered Copper-Based Coordination Polymers: Unveiling the Influence of the Ligand's Functional Group on their Electrochemical Properties
}

\author{
Marco Amores, ${ }^{* a, b, c}$ Keisuke Wada, ${ }^{b}$ Ken Sakaushi ${ }^{* a}$ and Hiroshi Nishihara ${ }^{* b}$
}

a) Center for Green Research on Energy and Environmental Materials, National Institute for Materials Science 11 Namiki, Tsukuba, Ibaraki 305-0044, Japan. E-mail: sakaushi.ken@nims.go.jp

b) Department of Chemistry, School of Science, The University of Tokyo 7-3-1 Hongo, Bunkyo-ku, Tokyo 1130033, Japan. E-mail: marco.amores@chem.s.u-tokyo.ac.jp; nisihara@chem.s.u-tokyo.ac.jp

c) Japan Society for the Promotion of Science (JSPS) International Research Fellow, Ichibancho, Chiyoda-ku, Tokyo 102-8471, Japan.<smiles>Oc1cc(O)cc(O)c1</smiles><smiles>O=[N+]([O-])c1c(O)c([N+](=O)[O-])c(O)c([N+](=O)[O-])c1O</smiles><smiles>Nc1c(O)c([NH3+])c(O)c([NH3+])c1O</smiles>

Scheme S1: Schematic representation of the triaminophloroglucinol ligand from phloroglucinol starting material.

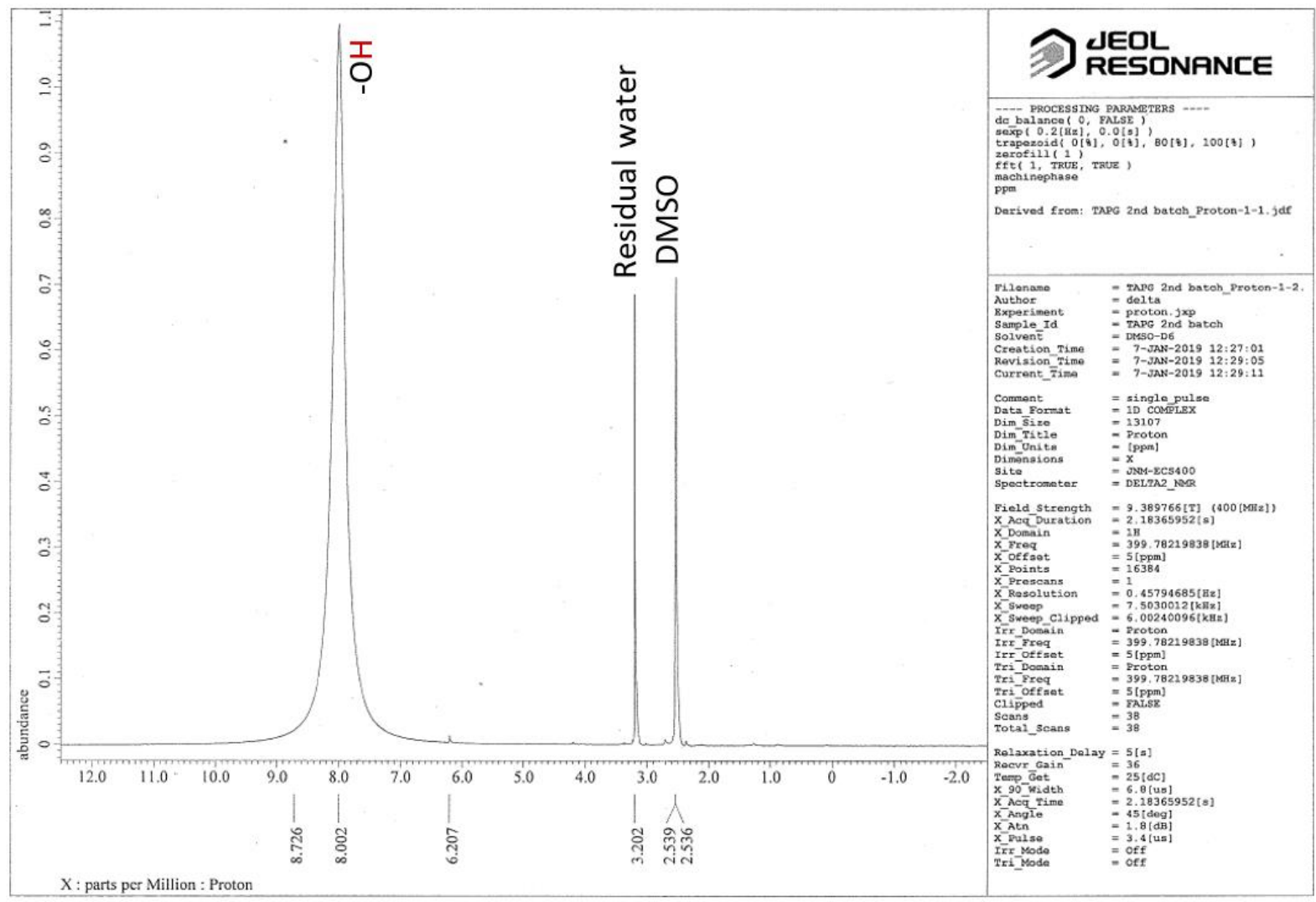

Figure S1: ${ }^{1} \mathrm{H}$ NMR of the triaminophloroglucinol in $\mathrm{d}_{6}-\mathrm{DMSO}$. 


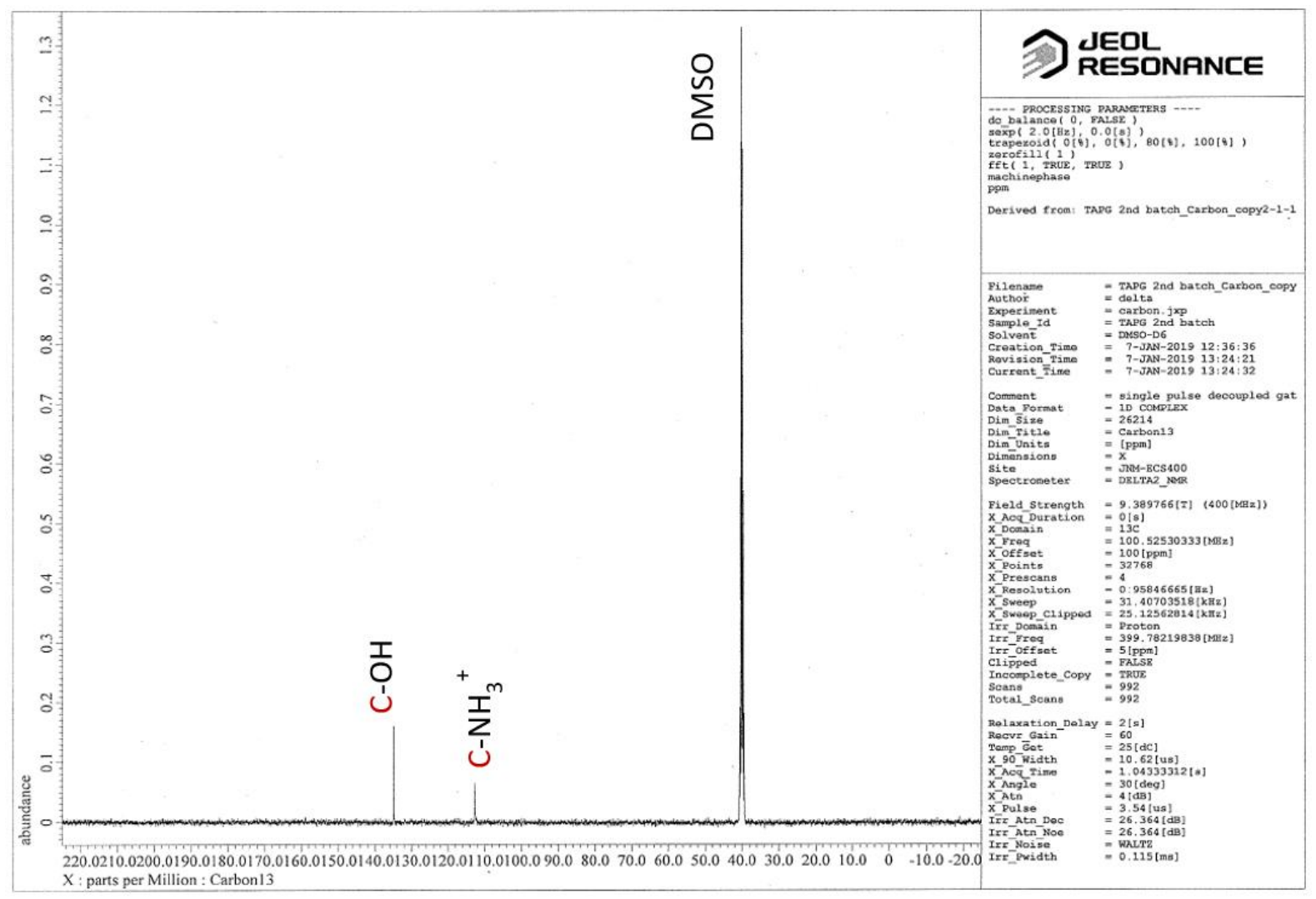

Figure S2: ${ }^{13} \mathrm{C}$ NMR of the triaminophloroglucinol ligand in $\mathrm{d}_{6}-\mathrm{DMSO}$.<smiles>c1ccc2c(c1)NC1(N2)Oc2ccccc2O1</smiles>

Figure S3: Molecular unit of $\mathrm{Cu}(\mathrm{IP})_{2}$ mononuclear complex.

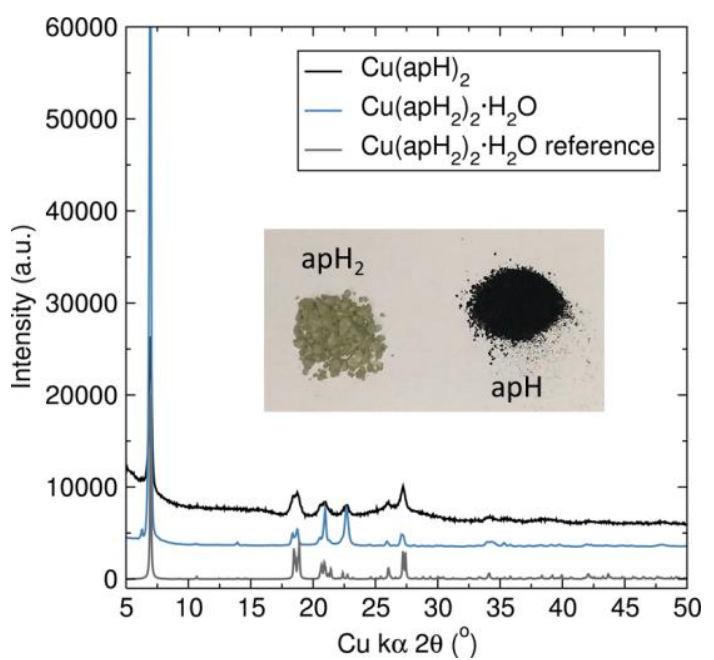

Figure S4: PXRD of the reference and synthesised protonated $\mathrm{Cu}(\mathrm{AP})_{2}\left[\mathrm{Cu}\left(\mathrm{apH}_{2}\right) \cdot \mathrm{H}_{2} \mathrm{O}\right]$ with $\mathrm{P} \overline{\mathbf{1}}$ space group, ${ }^{1}$ and deprotonated $\mathrm{Cu}(\mathrm{IP})_{2}\left[\mathrm{Cu}(\mathrm{apH})_{2}\right]$. A clear colour change is observed upon deprotonation while crystallinity structure is retained. Inset: Photographs of protonated and deprotonated $\mathrm{Cu}(\mathrm{IP})_{2}$. 

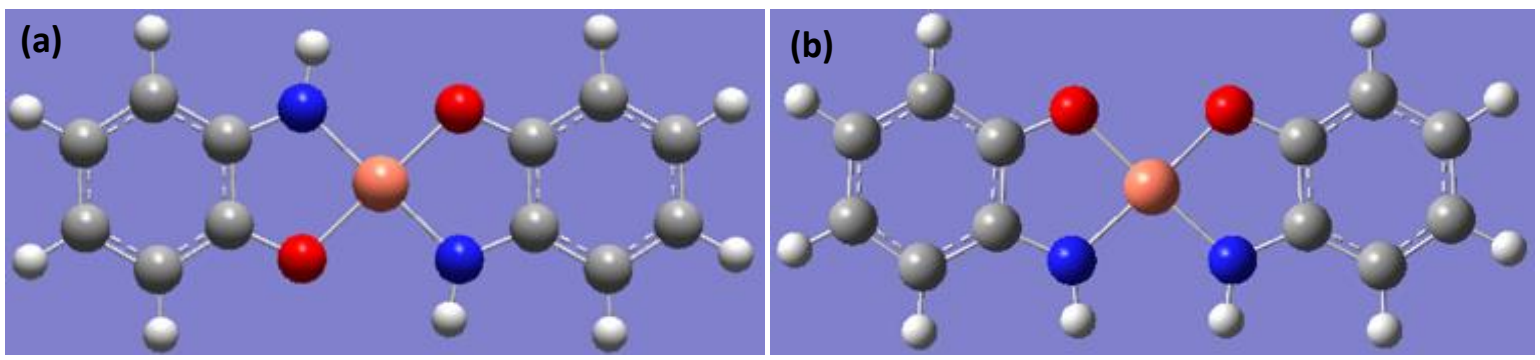

Figure S5: DFT optimised structures using the B3LYP functional and the 6-31G basis set for the $\mathrm{Cu}(\mathrm{IP})_{2}$ mononuclear complex in trans (a) and cis (b) configurations.

Elemental Analyses of Cu-containing coordination polymers

$\begin{array}{lcccc} & \mathbf{C}(\% \mathrm{wt}) & \mathbf{N}(\% \mathrm{wt}) & \mathbf{H}(\% \mathrm{wt}) & \text { Reference } \\ \mathrm{Cu}_{3}(\mathrm{HIB})_{2} \text { calculated } & 27.99 & 32.64 & 2.35 & \\ \mathrm{Cu}_{3}(\mathrm{HIB})_{2} \text { experimental this work } & 26.73 & 27.76 & 2.4 & \\ \mathrm{Cu}_{3}(\mathrm{HIB})_{2} \text { literature } & 22.77 & 23.85 & 2.24 & \text { Nat. Energy, 2018, 3, } 30 \\ \mathrm{Cu}_{3}(\mathrm{TIPG})_{2} \text { calculated } & 27.67 & 16.14 & 1.16 & \\ \mathrm{Cu}_{3}(\mathrm{TIPG})_{2} \text { experimental this work } & 26.28 & 20.82 & 1.7 & \\ \mathrm{Cu}_{3}(\mathrm{HAB})_{2} \text { calculated } & 27.36 & 0 & 0 & \\ \mathrm{Cu}_{3}(\mathrm{HAB})_{2} \text { experimental this work } & 25.19 & 5.53 & 1.76 & \\ \mathrm{Cu}_{3}(\mathrm{HAB})_{2} \text { literature } & 26.06 & 5.97 & 2.23 & \text { J. Am. Chem. Soc. 2018, 140, 14533 }\end{array}$

Table S1: Elemental analysis results for the three Cu-containing coordination polymers studied in this work. $\mathrm{Cu}_{3}(\mathrm{HIB})_{2}$ presents lower percentages of $\mathrm{C}$ and $\mathrm{N}$ and higher percentage of $\mathrm{H}$ than expected which is attributed to presence of water molecules in the case of the $\mathrm{Cu}_{3}(\mathrm{HIB})_{2}$, and in the case of the $\mathrm{Cu}_{3}(\mathrm{TIPG})_{2}$ and $\mathrm{Cu}_{3}(\mathrm{HAB})_{2}$ higher values of $\mathrm{N}$ and $\mathrm{H}$ are obtained which are ascribed to presence of $\mathrm{NH}_{4}{ }^{+}$in the case of $\mathrm{Cu}_{3}(\mathrm{TIPG})_{2}$ and to ethylenediamine in the case of $\mathrm{Cu}_{3}(\mathrm{HAB})_{2}$ in line with the results previously reported for these materials. ${ }^{2,3}$
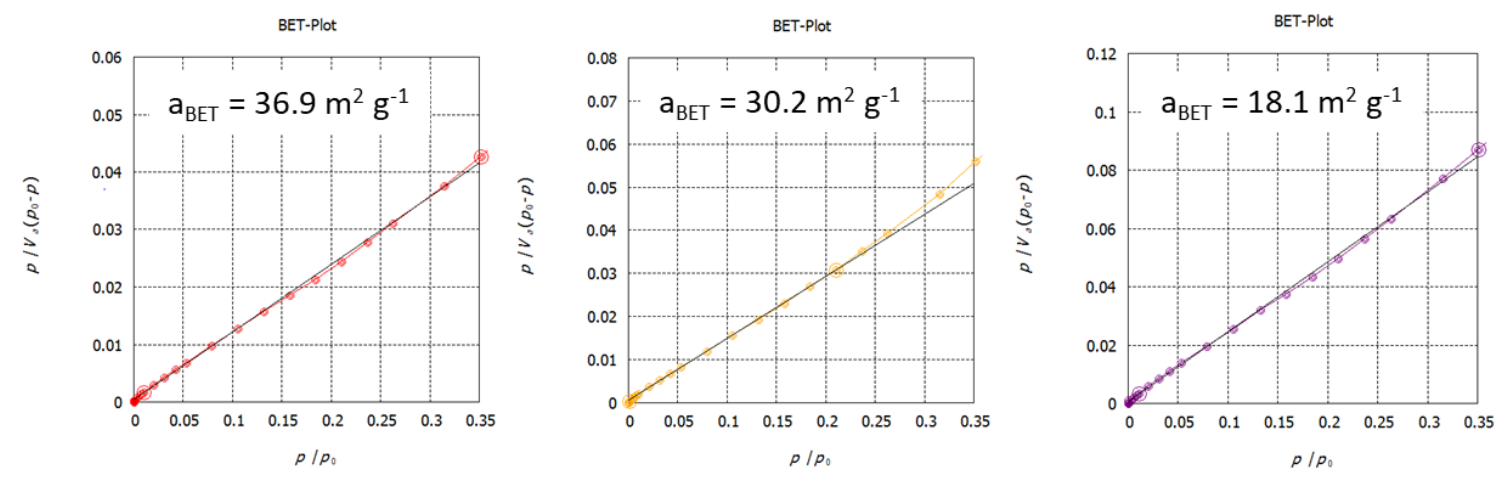

Figure S6: BET analyses of the $\mathrm{N}_{2}$ adsorption measurements for the three $\mathrm{Cu}$-based coordination polymers studied in this work: $\mathrm{Cu}_{3}(\mathrm{HIB})_{2}$ (red), $\mathrm{Cu}_{3}(\mathrm{TIPG})_{2}$ (orange) and $\mathrm{Cu}_{3}(\mathrm{HIB})_{2}$ (purple). 

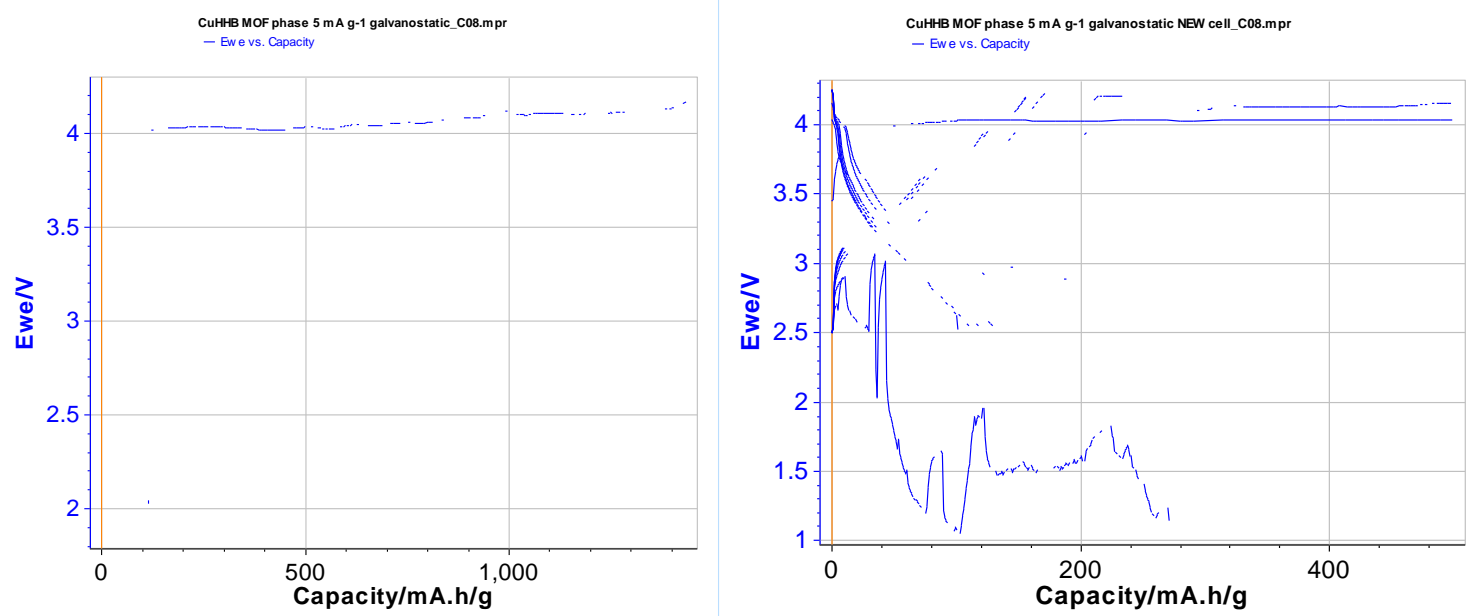

Figure S7: Galvanostatic cycling of the $\mathrm{Cu}_{3}(\mathrm{HAB})_{2}$ coordination polymer at $5 \mathrm{~mA} \mathrm{~h}^{-1}$ between 4.25 and $2.5 \mathrm{~V}$. A long plateau above $4 \mathrm{~V}$ is observed where cell was stoped the first two cycles, allowing the cell to cycle for a few additional cycles without limiting the charging capacity.
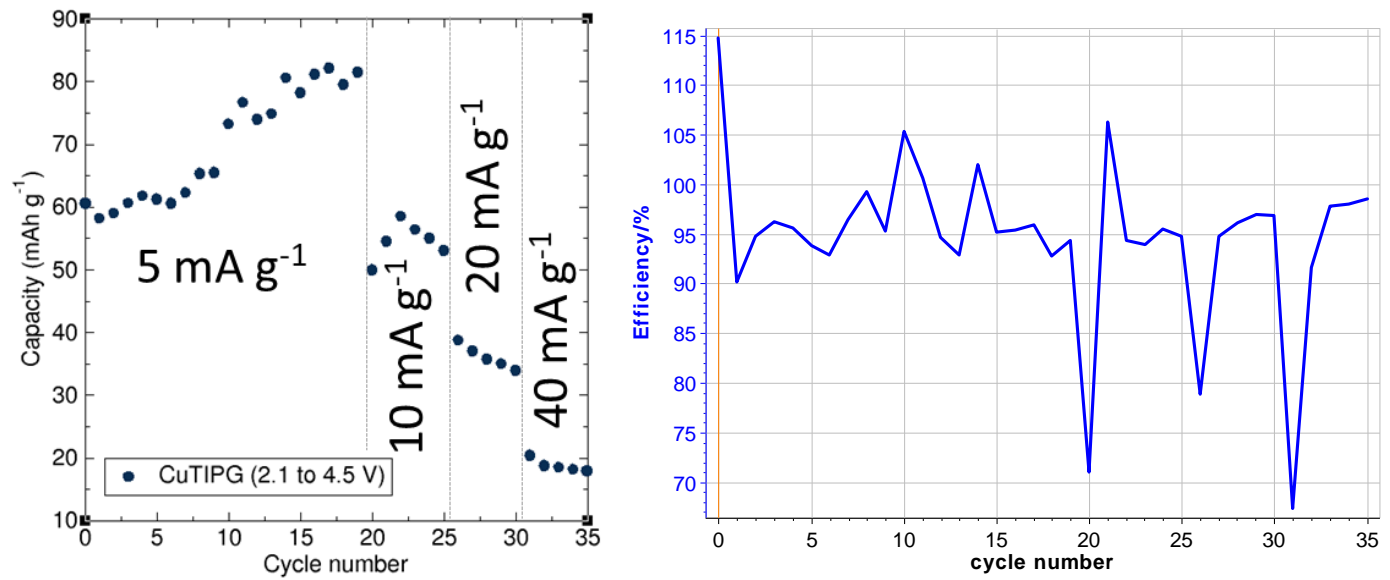

Figure S8: (a) Discharge capacity obtained at different cyclin rates for the $\mathrm{Cu}_{3}(\mathrm{TIPG})_{2}$ coordination polymer on a wider voltage window, 4.5-2.2 V. (b) Coulombic efficiencies every cycle of the rate capability test in (a). 

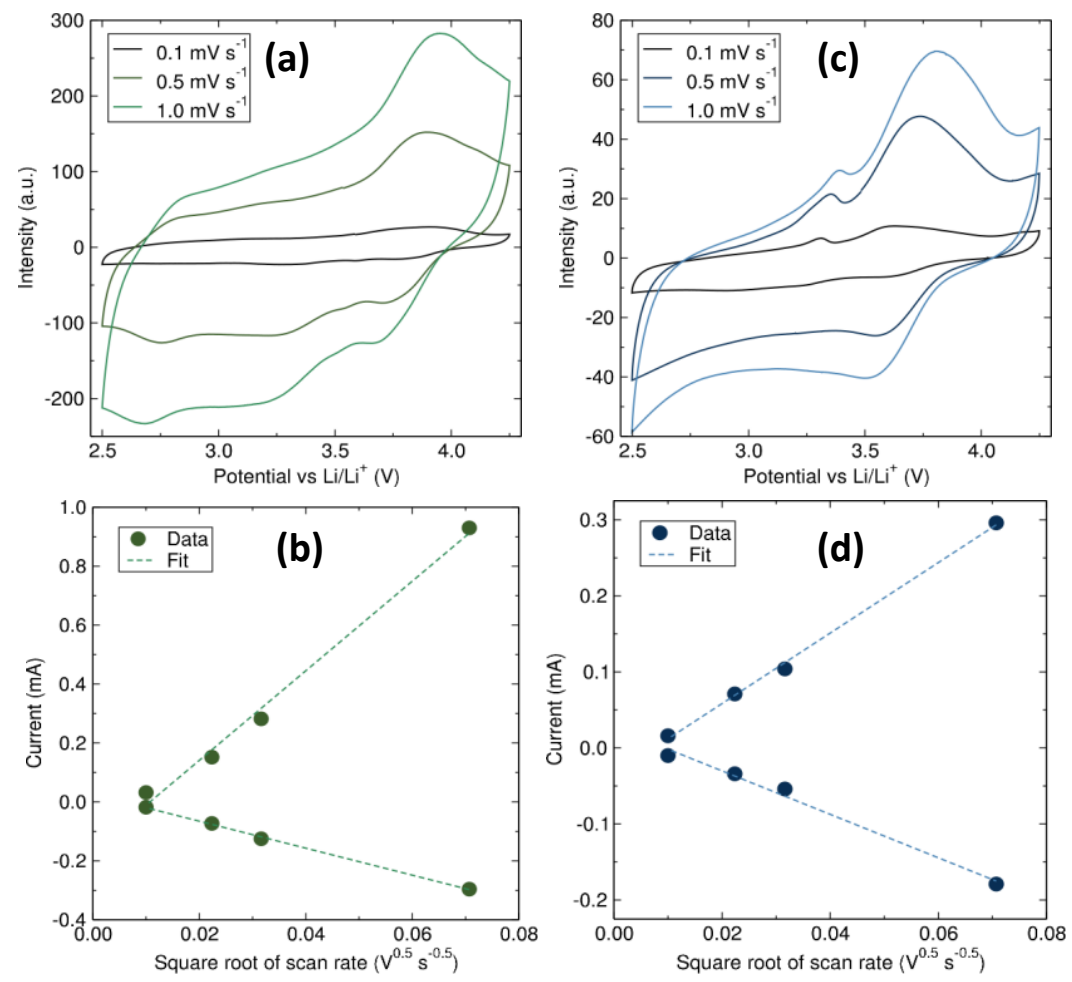

Figure S9: Cyclic voltammograms at different scan rates $(a, b)$ for the $\mathrm{Cu}_{3}(\mathrm{HIB})_{2}$ and $\mathrm{Cu}_{3}(\mathrm{TIPG})_{2}$ coordination polymers and linear fits of the peak current in function of the scan rate's square root $(c, d)$.

Randles-Sevcik equation for a 1-electron reaction: $I_{p}=0.4463 F(F / R T)^{1 / 2} C v^{1 / 2} A D^{1 / 2}$

\section{Where:}

$I_{p}=$ intensity of redox peat at the maximum $|I|$

$\mathrm{C}=$ concentration of $\mathrm{Li}^{+} / \mathrm{PF}_{6}-$ in electrolyte $=10^{-3} \mathrm{~mol} \mathrm{~cm}^{3}$

$A=$ area of electrode $=2 \mathrm{~cm}^{2}$

$\mathrm{F}=$ Faraday constant

$\mathrm{R}=$ gas constant

$\mathrm{T}=$ temperature of experiment $=25^{\circ} \mathrm{C}$

$v=$ scan rate

$\mathrm{D}=$ diffusion coefficient

\begin{tabular}{|c|c|c|}
\hline & $\mathrm{Cu}_{3}(\mathrm{HIB})_{2}$ & $\mathrm{Cu}_{3}(\mathrm{TIPG})_{2}$ \\
\hline Oxidation & $8.0 \times 10^{-10} \mathrm{~cm}^{2} \mathrm{~s}^{-1}$ & $7.3 \times 10^{-11} \mathrm{~cm}^{2} \mathrm{~s}^{-1}$ \\
\hline Reduction & $7.3 \times 10^{-11} \mathrm{~cm}^{2} \mathrm{~s}^{-1}$ & $2.9 \times 10^{-11} \mathrm{~cm}^{2} \mathrm{~s}^{-1}$ \\
\hline
\end{tabular}

Table S2: Calculated ionic diffusion coefficients for the $\mathrm{Cu}_{3}(\mathrm{HIB})_{2}$ and $\mathrm{Cu}_{3}(\mathrm{TIPG})_{2}$ coordination polymers on the 3.9/3.8 and 3.6/3.6 V redox couples, respectively, from fits to the Randles-Sevcik equation. 

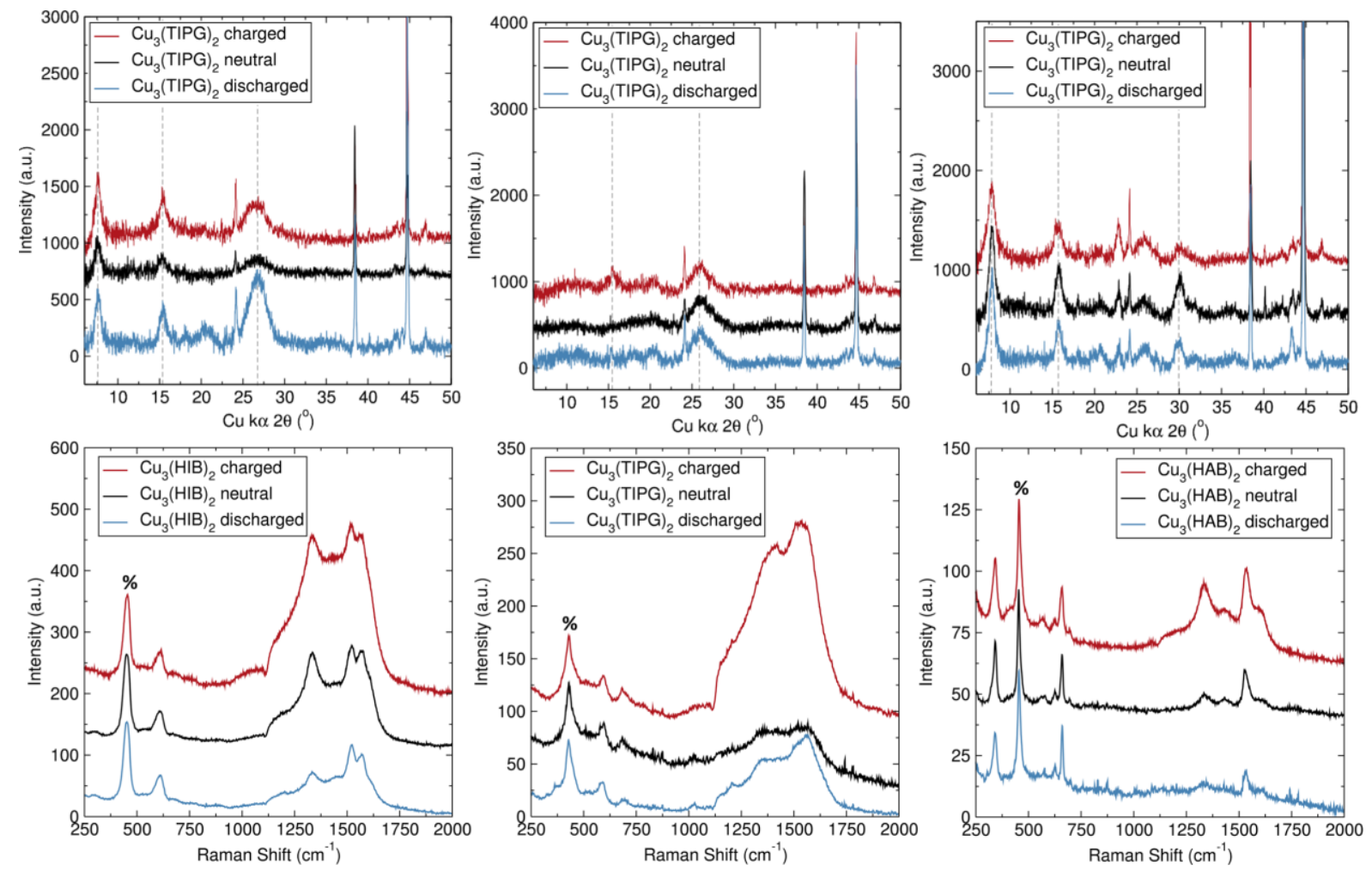

Figure S10: Ex-situ PXRD (top) and Raman spectra (bottom) of cycled electrodes of the three copper-containing coordination polymers at three charged (4.25 V), neutral (OCV) and discharged (2.5 V). Raman data have been rescaled to normalise the intensity to that of the vibration band marked with the \% symbol in order to compare the relative intensities between the $\mathrm{Cu}-\mathrm{X}$ and aromatic ring vibrations. 


\section{XPS fits}

$\mathrm{Cu}_{3}(\mathrm{HIB})_{2}$ discharged to $2.5 \mathrm{~V}$
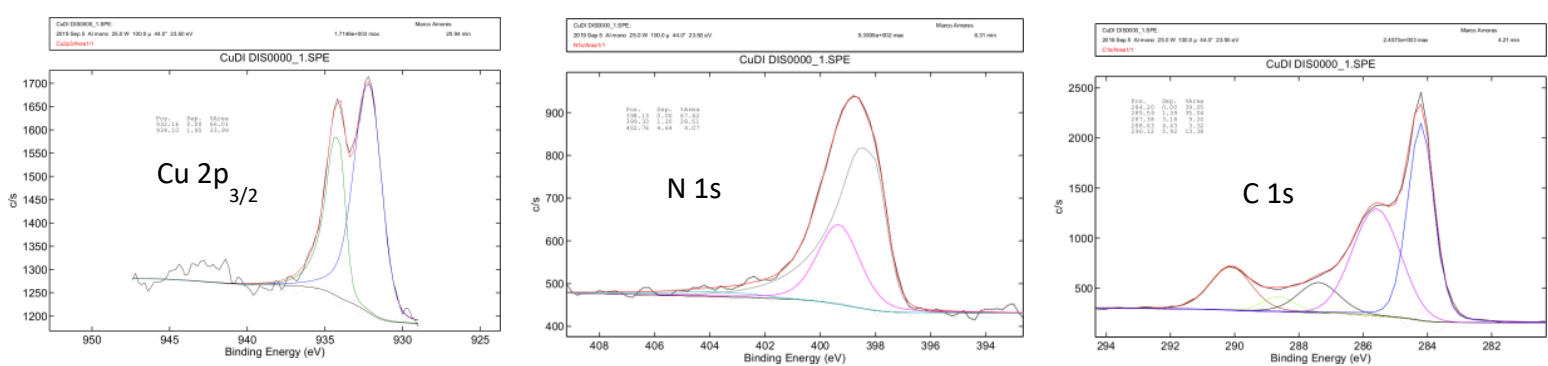

$\mathrm{Cu}_{3}(\mathrm{HIB})_{2}$ neutral at OCV
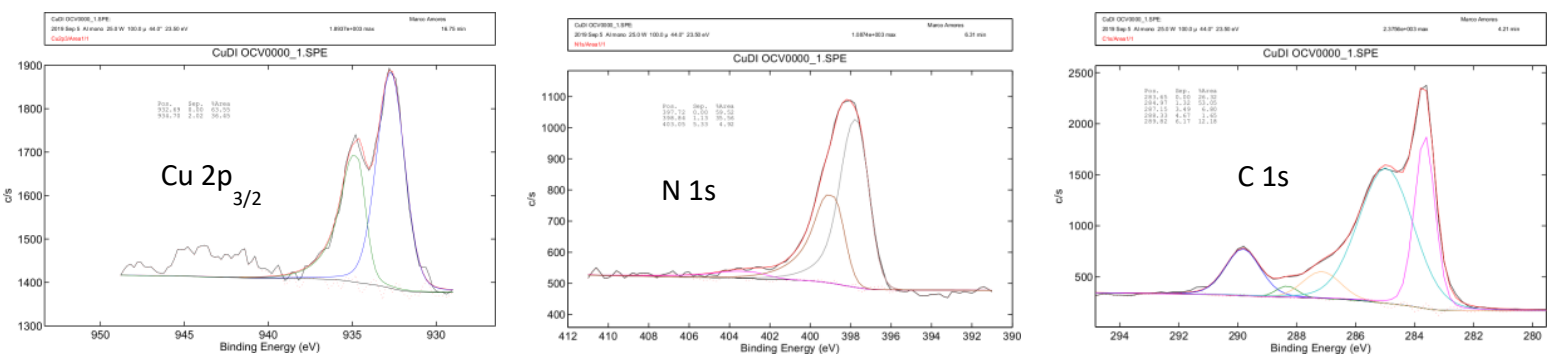

$\mathrm{Cu}_{3}(\mathrm{HIB})_{2}$ charged to $4.25 \mathrm{~V}$
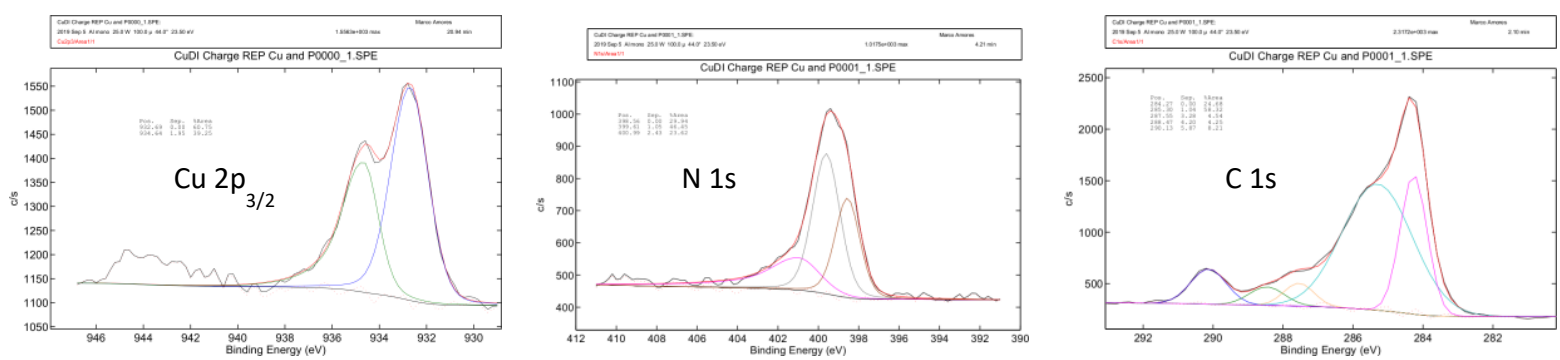
$\mathrm{Cu}_{3}(\mathrm{TIPG})_{2}$ discharged to $2.5 \mathrm{~V}$
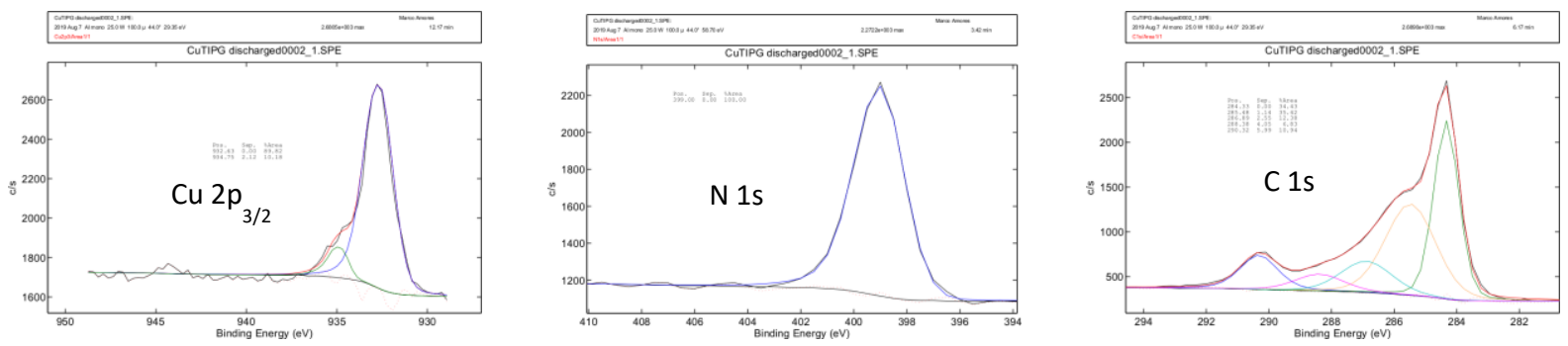

$\mathrm{Cu}_{3}(\mathrm{TIPG})_{2}$ neutral at $\mathrm{OCV}$
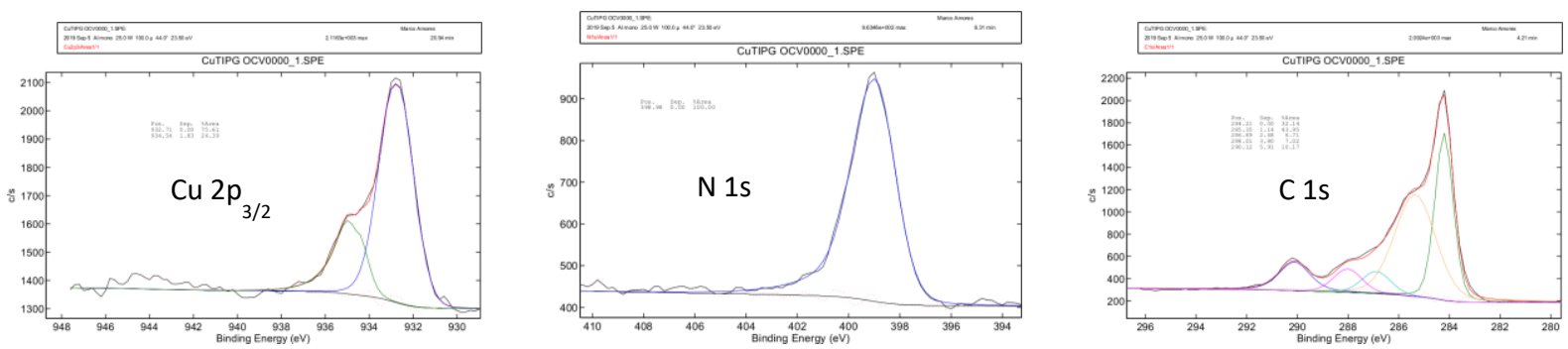

$\mathrm{Cu}_{3}(\mathrm{TIPG})_{2}$ charged to $4.25 \mathrm{~V}$
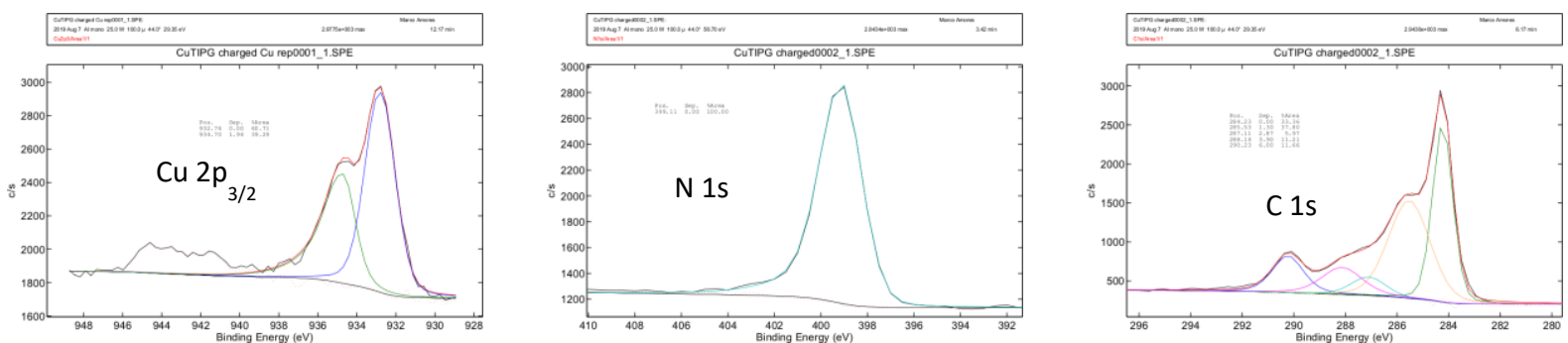
$\mathrm{Cu}_{3}(\mathrm{HAB})_{2}$ discharged to $2.5 \mathrm{~V}$
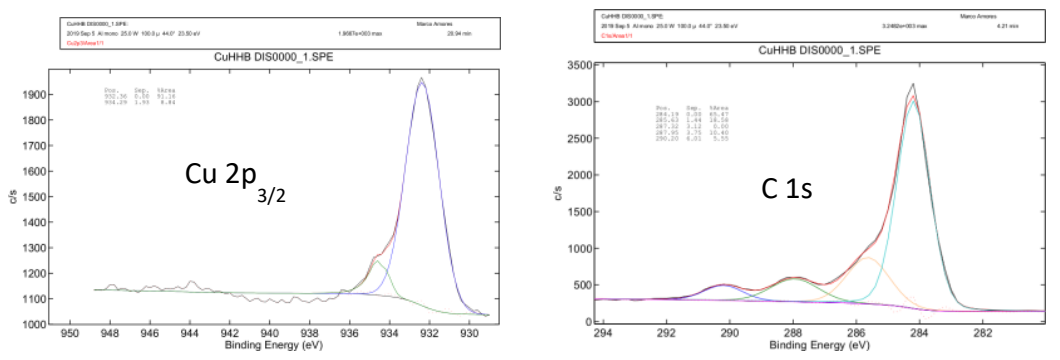

$\mathrm{Cu}_{3}(\mathrm{HAB})_{2}$ neutral at OCV
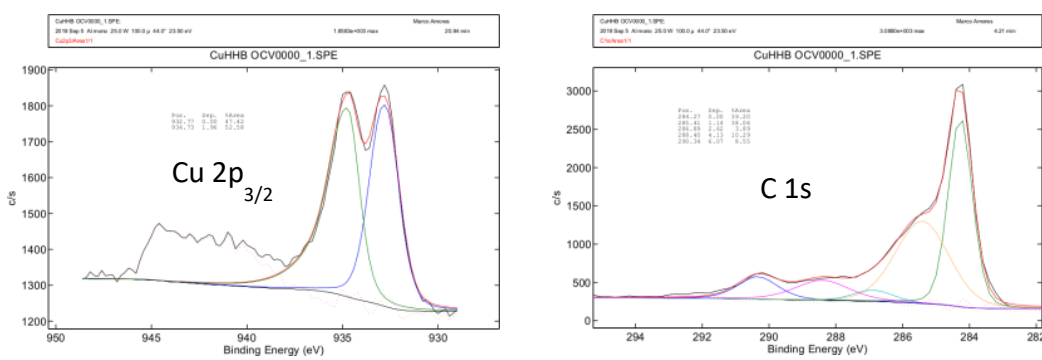

$\mathrm{Cu}_{3}(\mathrm{HAB})_{2}$ charged to $4.25 \mathrm{~V}$
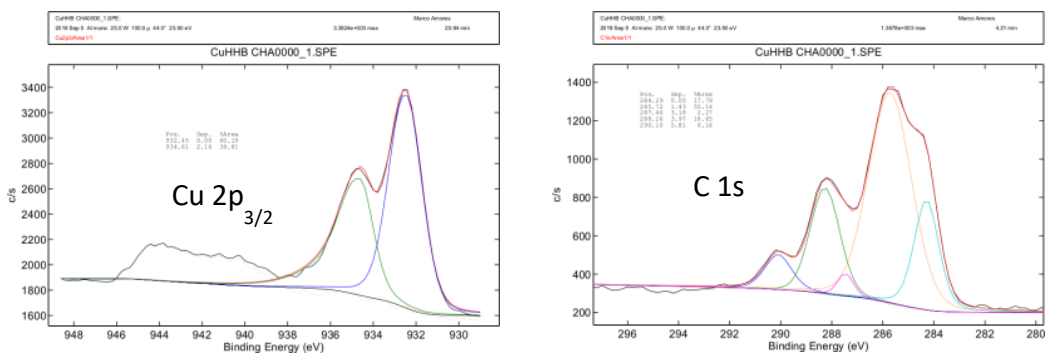


\section{References:}

1 M. Wakizaka, T. Matsumoto, R. Tanaka and H.-C. Chang, Dehydrogenation of anhydrous methanol at room temperature by o-aminophenol-based photocatalysts, Nat. Commun., 2016, 7, 12333.

2 D. Feng, T. Lei, M. R. Lukatskaya, J. Park, Z. Huang, M. Lee, L. Shaw, S. Chen, A. A. Yakovenko, A. Kulkarni, J. Xiao, K. Fredrickson, J. B. Tok, X. Zou, Y. Cui and Z. Bao, Robust and conductive twodimensional metal-organic frameworks with exceptionally high volumetric and areal capacitance, Nat. Energy, 2018, 3, 30-36.

3 J. Park, A. C. Hinckley, Z. Huang, D. Feng, A. A. Yakovenko, M. Lee, S. Chen, X. Zou and Z. Bao, Synthetic routes for a 2D semiconductive copper hexahydroxybenzene metal-organic framework, J. Am. Chem. Soc., 2018, 140, 14533-14537. 